\title{
DESIGN AND DEVELOPMENT OF ACCOUNTING INFORMATION SYSTEM FOR CASH SALES OF MILD STEEL
}

\author{
Ari Puspita ${ }^{1 *}$, Yuyun Yuningsih ${ }^{2}$, Muhammad Fahmi ${ }^{3}$, Rahmat Tri Yunandar ${ }^{4}$ \\ ${ }^{1,4}$ Sistem Informasi \\ Universitas Bina Sarana Informatika \\ www.bsi.ac.id \\ ${ }^{1 *}$ ari.arp@bsi.ac.id , ${ }^{4}$ rahmat.rtr@bsi.ac.id \\ ${ }^{2}$ Sistem Informasi; ${ }^{3}$ Teknik Informatika \\ Univesitas Nusa Mandiri \\ www.nusamandiri.ac.id \\ 2 Yuyun.yyg@nusamandiri.ac.id, 33 fahmi.mmf@nusamandiri.ac.id \\ (*) Corresponding Author
}

\begin{abstract}
Abstrak
Perkembangan teknologi kini mengalami perkembangan yang sangat pesat, sehingga banyak pengusaha berlomba-lomba untuk menghasilkan perusahaan baru. Pada saat ini bisnis baja ringan berkembang pesat. Peneliti mencoba membuat penelitian mengenai sistem penjualan baja ringan yang kebanyakan perusahaan belum memiliki sistem pencatatan yang terkomputerisasi, sehingga terhambatnya pada proses penginputan faktur, serta nota penjualan yang masih ditulis secara manual sampai dengan pembuatan laporannya sehingga akan memakan waktu yang lama. Dalam pembuatan sistem informasi tersebut penulis akan menggunakan model waterfall dan untuk pembuatan perangkat lunak ini akan menggunakan bahasa pemograman php. Tujuan dari pembuatan sistem informasi penjualan ini adalah untuk mempermudah dalam menjalani sistem penjualan baja ringan sehingga dapat mempersingkat waktu pengerjaan dan meminimalisir dari segala bentuk kesalahan dalam pembuatan laporan.
\end{abstract}

Kata kunci: Sistem penjualan, Perangkat Lunak, Waterfall.

\begin{abstract}
Technological developments are now experiencing rapid growth, so many entrepreneurs compete to produce new companies. At this time, the light steel business is multiplying. The researcher tries to research the weak steel sales system. Most companies do not have a computerized recording system, so inputting invoices is hampered. Sales notes are written manually to report generation, so that it will take a long time. In making the information system, the author will use the waterfall model and will use the PHP programming language for the manufacture of this software. The purpose of making this sales information system is to make it easier to carry out a mild steel sales system to shorten processing time and minimize all forms of errors in reporting.
\end{abstract}

Keywords: Sales System, Software, Waterfall

\section{INTRODUCTION}

Sales are the most critical activity in every company or business entity, especially manufacturing and trading companies. Efficient sales are expected to increase sales of goods (Darmawan \& Firmansyah, 2018), With a mature and appropriate strategy, sales will increase cash and credit sales. (Sitorus, Maria Christina \& Kuriawan, 2021).

Likewise, this business has a very growing potential in the light steel business world. For example, nowadays, there is a lot of housing in big cities and in regions that use mild steel as the primary material for construction.

The sales system is usually also influenced by the payment system. Two payment systems are commonly used, namely cash and credit sales systems. Wherefrom the results of research on the Syifa shop that sells goods with both systems, and has carried out a comparative test between the two payment methods, so that the results from the study show that the average buyer decides to use the cash payment method compared to the credit payment method. (Maknunah \& Lestari, 2018).

Internet technology has proven to be one of the most effective and efficient information media in 
disseminating information that anyone can access anytime and anywhere. Internet technology also has a significant effect on commerce or business. Because only from home or office, prospective buyers can view access and compare the products to be purchased. With online sales, prospective buyers can save time and costs because they don't have to bother coming directly to the store or place of transaction. (Iriadi \& Rosdiana, 2017)

A company or business entity carrying out the buying and selling process requires a sound recording system. Then it can produce accurate financial reports for consideration in deciding previous research conducted at PT Sanggraha Property, where sales recorders still use a manual system so that in creating financial information, they are still made globally. In contrast, sales data must be taken from several sales staff. This causes the preparation of financial reports to be very long and has problems, namely difficulties in getting sales data from the sales staff. Searching for transaction data takes a long time, and making reports cannot be done in a short time. (Riswaya, 2013)

In addition, other research was carried out by wira at the Satria cellphone shop where the purpose of this study was to find out the weaknesses of the manual recording system, obtain an overview of the cash sales system, time efficiency in the implementation of sales, whether the data obtained were accurate and reduce losses incurred. Occur. From these problems, a solution is obtained, namely by changing the manual disability system into a computerized recording system that can make the process of disability easier, and all problems can be overcome. (Hartono, 2018)

Then at PT. Cahaya Sejahtera Sentosa is engaged in the business sector. The buying and selling process is still done manually. The marketing and product promotion process only covers certain areas and is very limited, and can only rely on the marketing system by ordering by telephone and product introduction. Done conventionally, namely using the door to doo and one-to-one relationships for prospective buyers to see product information needed and traded, prospective buyers must come directly to the factory if they want to know more detailed information. (Prasetyo \& Susanti, 2015)

Then research on PT. Inter Aneka Plasindo, where this company is engaged in the Plastic Packaging Industry. in the sales process, sales data is recorded on the sales form. The information is inputted using Microsoft Excel. In recording data like this, it is still not practical because of a large number of books to record/input the sales process; thus, errors and mistakes often occur in inputting and searching for data. This resulted in a lot of time- consuming in the preparation of the report. So the management of sales data is still not optimal because there is often a data mismatch between the warehouse section and the finance department. (Sudaryono \& Rahwanto, 2020)

From several previous research results, many records of sales in cash are still made manually, which is the background for the author to conduct this research to design a computerized accounting disability information system to provide an accurate and accurate recording of financial reports, and in financial records no longer takes a long time.

\section{RESEARCH METHODS}

\section{Types of research}

The type of research used by the author is descriptive qualitative research, where analysis is carried out directly to data sources, and data collection is carried out where the data is used to examine an object, a condition, or an event that is currently happening. (Hartono, 2018)

\section{Time and Place of Research}

The place of research was conducted at a private company in the DKI Jakarta area. Research time in April 2021 to June 2021.

\section{Research Target / Subject}

This research targets a company or business entity engaged in sales, where sales use the cash payment method, and the recording of financial statements still uses the manual process.

\section{Procedure}

The method used in this qualitative research is based on the SDLC (System Life Cycle) (Puspita et al., 2019) By using the waterfall model. The following are the stages in the waterfall model:

1. Stages of preparation

At this stage, the researcher prepares anything related to the manual recording of financial statements, formulates problems often encountered by business entities, identifies existing problems, makes the aims and objectives of the research conducted, and studies literature related to the investigation. It is being undertaken.

2. Stages of data collection

At this stage, the data collection technique is to make direct observations or observations and collect from the various previous research literature.

3. Analysis of software requirements

The author collects data needs from the system such as item data, sales transaction data, and also sales report data. 


\section{System Design}

In the design stage, the author makes ERD (Entity Relationship Diagram) and LRS (Logical Record Structure) the initial database that will be implemented as data used to manage all existing data on the system created.

5. Program Code Generation

At this stage, the author makes the program code used in the design. Which later serves as a translator of the design into a language known by the computer (Aediyansyah, 2018)

6. Testing

At this stage, the author conducts tests that focus on the software's logic and function and ensures that all code has been successfully tested. In this testing stage, the author uses Black box testing.(Oktaviani et al., 2020)

7. Support

The development of the information system that has been created, where changes are made to the system related to the hardware and software used.

8. Stages of results and suggestions

The stage is the core of the overall description and discussion of the previous chapters and the suggestions needed in this research to develop further.

\section{Data, Instruments, and Data Collection Techniques}

Data and information about existing systems are obtained in several ways, namely by conducting questions and answers or interviews, which are methods of analysis and data collection by executing a question and answer process with resource persons. (Muthia et al., 2019) With customers, owners, and actors in the sales process itself. From the question and answer process, the problems faced by business entities are obtained and obtain an overview of the sales information system, which is expected to solve manual sales system problems. Next, do the Observation. Observation is conducting direct observations at the sales department to observe the actual state of the object to be studied to obtain objective data from the company (Muthia et al., 2019). To obtain an overview of the design that will apply, observing the sales system currently being implemented is carried out. It follows the computerized system that will be applied and analyzed the document. So that the appropriate design for the company is obtained. In addition to carrying out the above activities, the author also conducts a literature study through the literature or references in several libraries and the internet as comparison materials and connections related to problems related to this writing.(Yuningsih, 2019)

\section{RESULTS AND DISCUSSION}

\section{A. Analysis of Software Requirements}

This private company is a company that is engaged in selling as a distributor of mild steel to facilitate the work of employees, and it requires a valuable information system to input sales invoices to make sales reports.

This stage of needs analysis is the most critical (Susanti, 2019). The researcher will plan for the information system to be built, and the researcher will analyze the need for the development of the information system.

The following is an analysis of the requirements needed for a mild steel sales system, namely:

1. Admin
a. Can manage item data
b. Can manage factory data
c. Can manage user data
d. Can manage category data
e. Can manage stock data
f. Can manage sales report data

2. Sales Department
a. Can manage transaction data
b. Can manage sales return data
c. Can manage sales journal data
d. Can manage sales report data

B. System Requirements Analysis

This sales information system has a system that will process all the needs used to control this sales information system. The following is an explanation of each design that has each function, namely:

1. The system limits the admin to log in first to access the admin page and log out to exit. Besides, that admin can also access item data, factory data, user data, category data, stock data, and sales report data. The admin can search, add, delete, edit, and save on that page.

2. The system limits the sales department to log in first to access the sales page. Besides that, the sales department can also access transaction data, sales return data, sales journal data. The sales department can search, add, delete, edit, and save on that page.

\section{Design}

\section{Use Case Diagrams}

Use case diagrams to describe the interactions between actors and each process carried out. (Prasetyo \& Susanti, 2015) the use case diagram for the light steel sales information system is as follows:

a. The use case diagram of the admin menu on the light steel sales information system can be seen in Figure 1 below: 


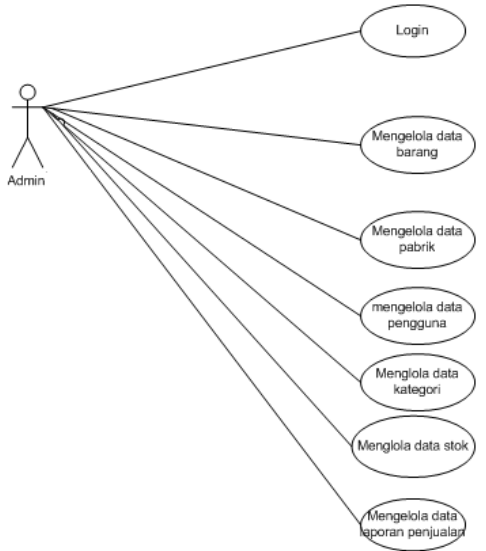

Figure 1. Use Case Diagram Admin Menu

In Figure 1, it is explained that the admin can access item data, factory data, user data, category data, stock data, sales report data.

b. The use case diagram of the sales menu on the light steel sales information system can be seen in Figure 2 below:

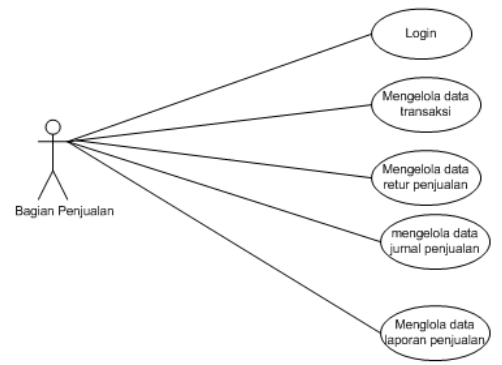

Figure 2. Use Case Diagram Menu Sales Section

In Figure 2, it is explained that the sales department can access transaction data, sales return data, sales journal data, sales report data.

\section{Activity Diagram}

Activity diagrams on the light steel sales information system are as follows:

a. Activity Diagram Login

The login activity diagram can be seen in Figure 3 below:

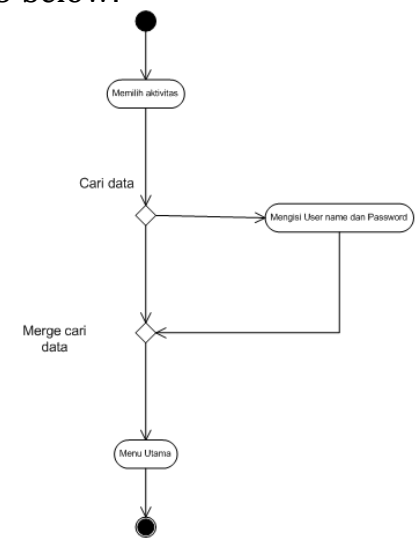

Figure 3. Activity Diagram Login
In figure 3, the login activity diagram starts from the admin inputting the username and password then clicking the login button, and the system checks the inputted username and password if they are valid according to the database then the admin can enter the main menu page if not then asked to repeat the login process.

3. Activity Diagram Menu Items

The item menu activity diagram can be seen in Figure 4 below:

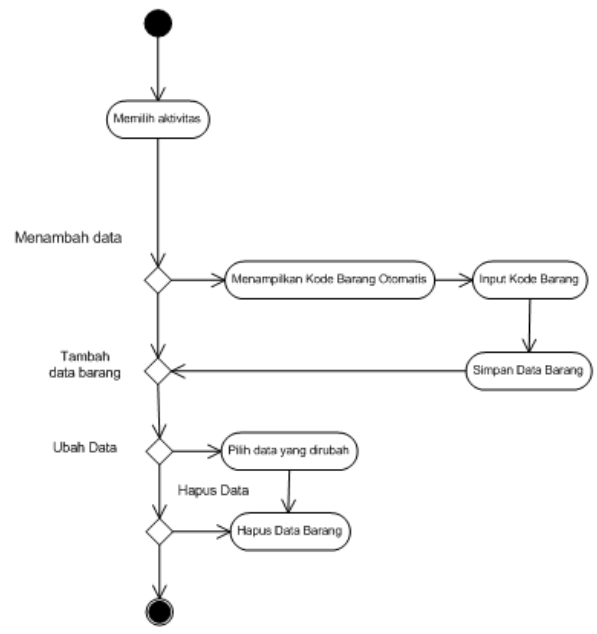

Figure 4. Activity Diagram Menu item

Figure 4 is an activity diagram for managing goods data. Activities carried out include adding, deleting, and editing item data.

4. Activity Diagram User Menu

User activity menu diagram can be seen in Figure 5 below:

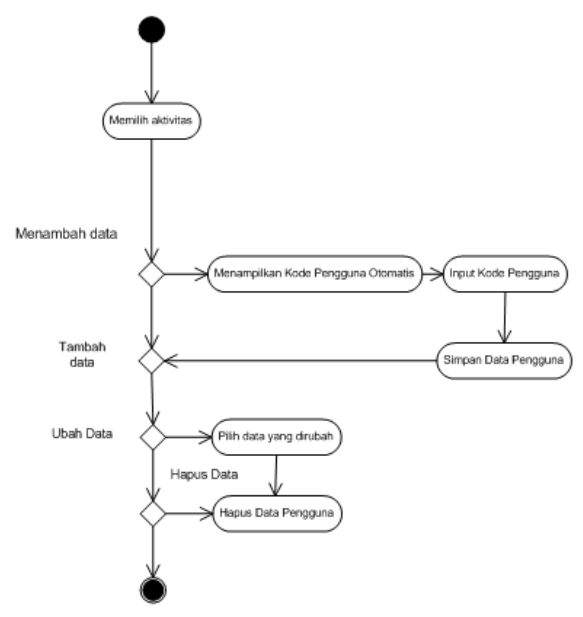

Figure 5. Activity Diagram User Menu

Figure 5 describes the activities of the use case managing user data. The user activity diagram starts from logging in and adding, deleting, editing or updating data. 


\section{Entity Relationship Diagram (ERD)}

Entity Relationship Diagram (ERD) light steel sales information system can be seen in the following figure 6 :

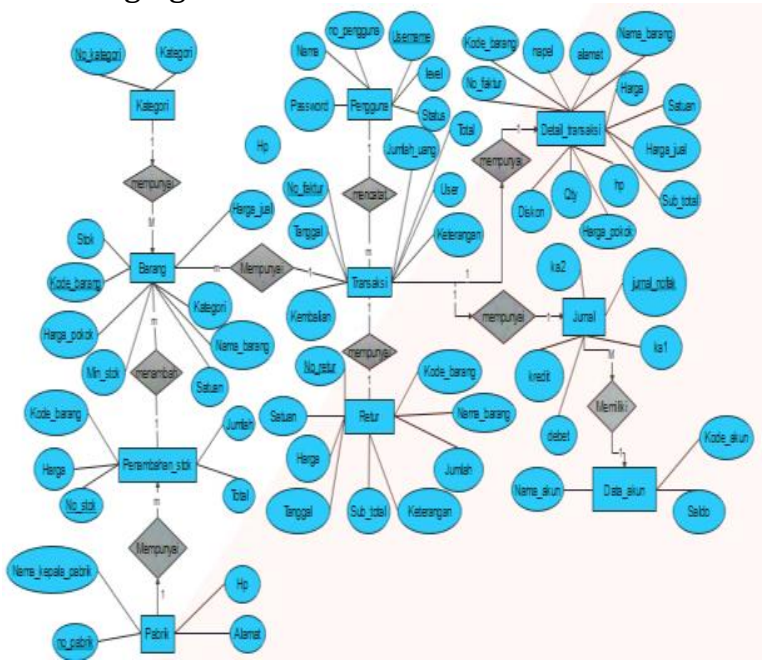

Figure 6. Entity Relationship Diagram (ERD)

Figure 6 describes the relationship between one entity and another. The picture explains that this system has 10 entities, namely: goods entity, factory entity, category entity, user entity, transaction entity, transaction detail entity, returns entity, journal entity, account data entity, and stock increase entity. Each entity has a one-to-one or oneto-many relationship. This diagram regulates the course of existing data documents in the database.

\section{Logical Record Structure (LRS)}

The Logical Record Structure (LRS) of the light steel sales information system can be seen in the following figure 7 :

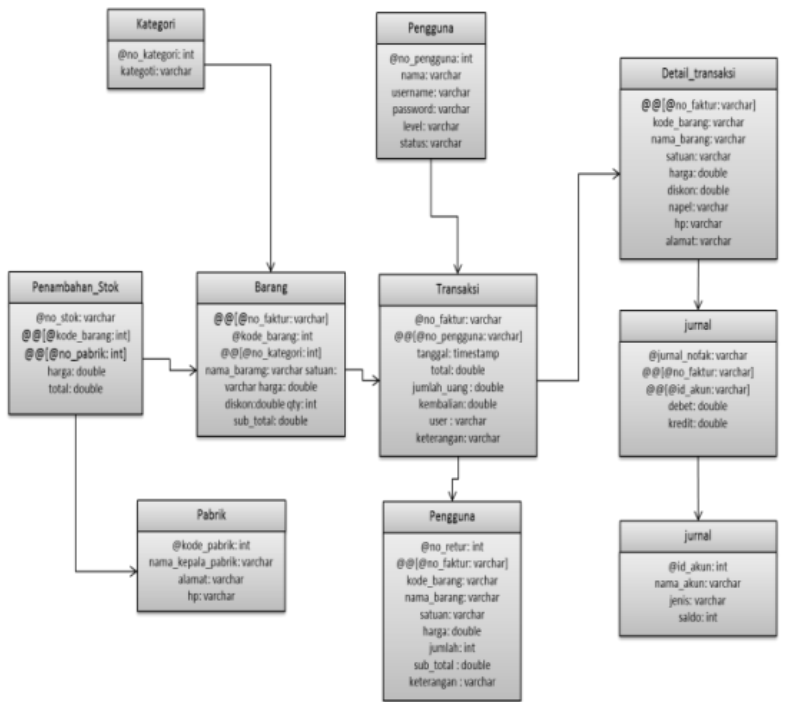

Source : (Frieyadie, 2019)

Figure 7. Logical Record Structure (LRS)
Figure 7 This Logical Record Structure (LRS) represents the record structure in tables formed from the results of relationships between entities.

\section{Class Diagram}

Class diagram of the light steel sales information system can be seen in Figure 8 below:

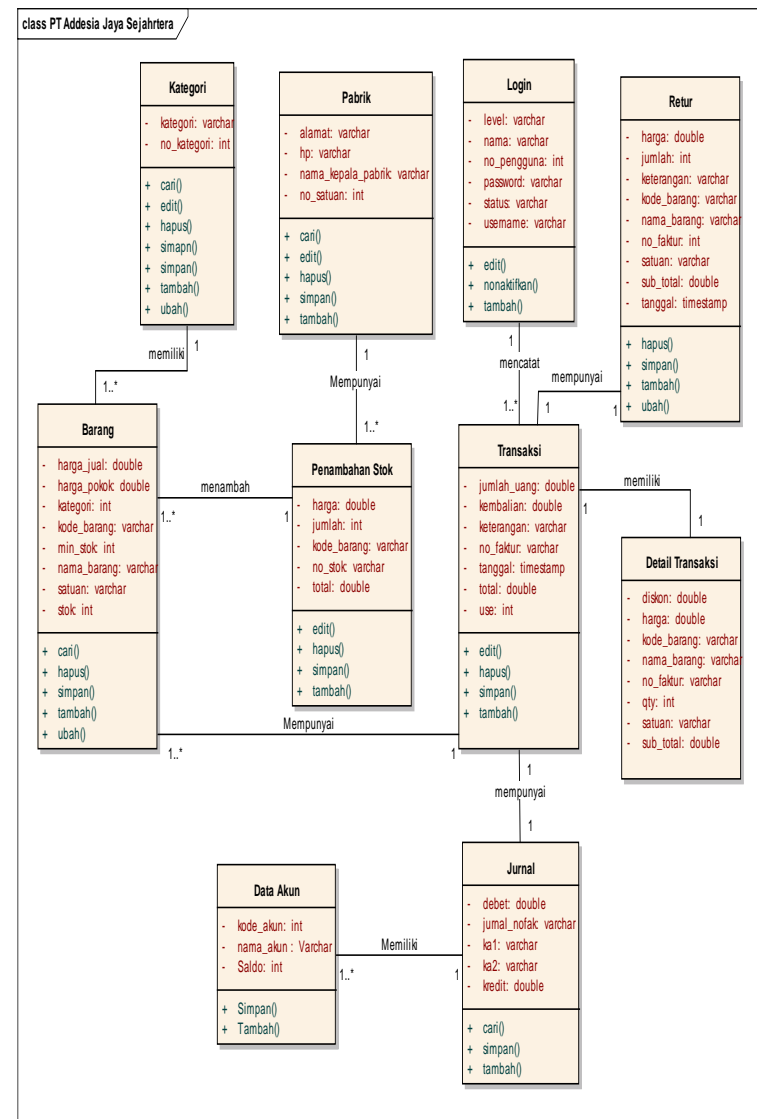

Figure 8. Class Diagram

Figure 8 describes the form of a class diagram, which depicts the system structure from the definition of classes in the light steel sales information system. In addition, there are attributes and methods created to operate this weak steel sales information system in the class.

\section{Sequence Diagram}

Sequence diagrams of goods and sales transactions in the light steel sales information system can be seen in Figure 9 below: 


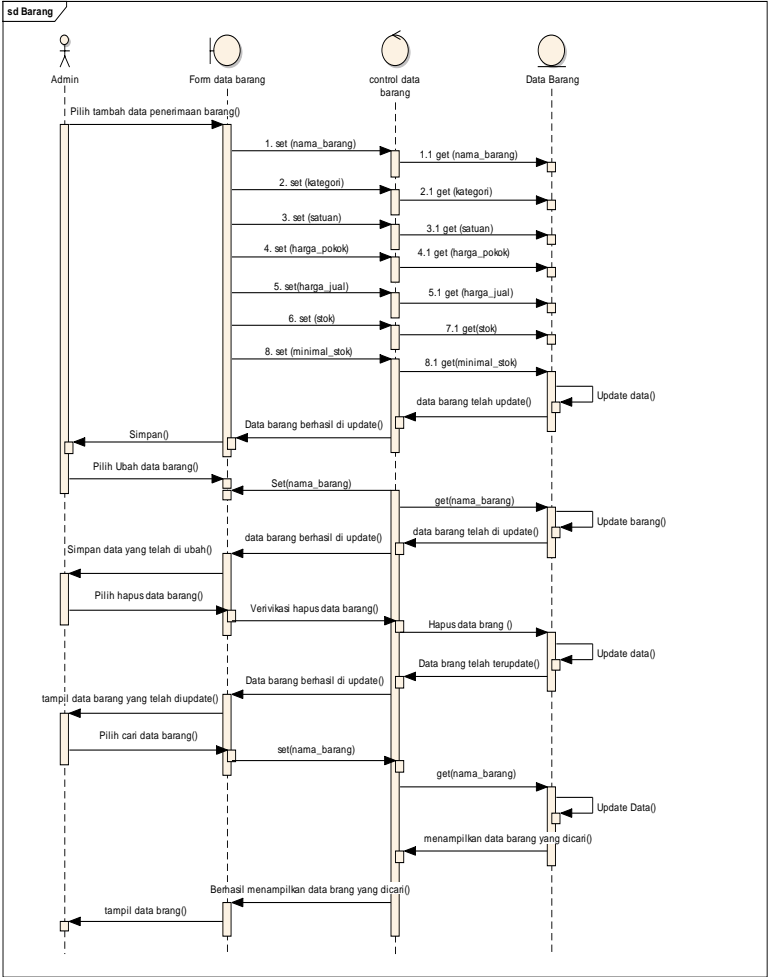

Figure 9. Sequence Diagram barang

Figure 9 is a sequence diagram of the goods, the image explains the interaction between objects. in the sequence diagram of the item there are objects that are executed by methods and functions or procedures and will produce an output.

\section{Deployment Diagram}

Deployment Diagram of the light steel sales information system can be seen in the following figure 19:

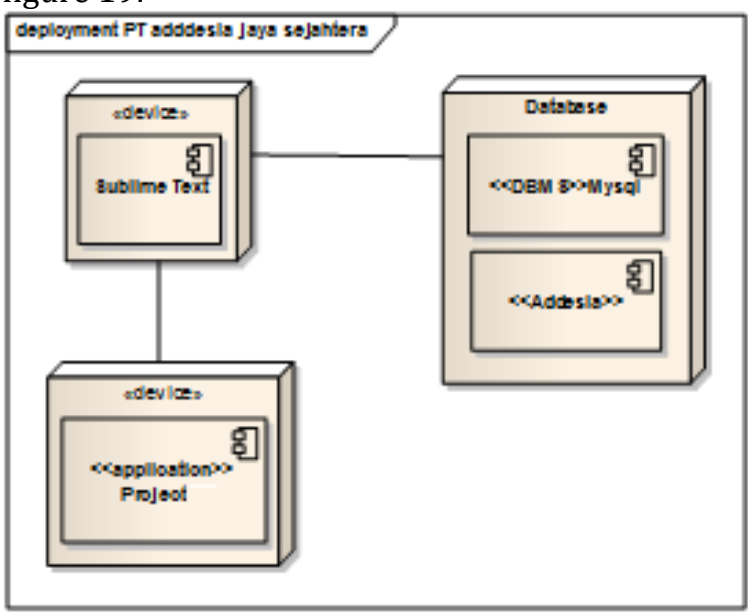

Figure 10. Deployment Diagram

In Figure 10 it is explained that this information system was created using a sublime text editor and using a MySQL database.

\section{User Interface}

\section{a. Login Menu}

The user interface for the login menu can be seen in Figure 11 below:

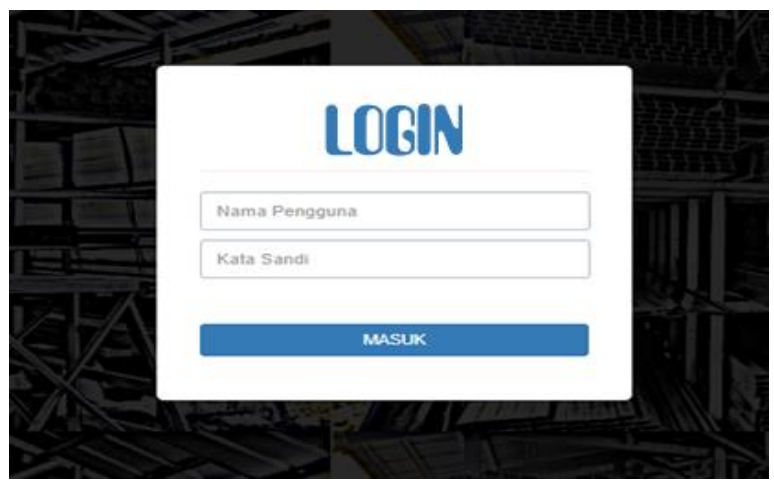

Figure 11. Login menu

Figure 11, there is a login form for the admin and the sales department where the admin and the sales department are required to enter a user name and password, click the login button, and join the main menu page.

\section{b. Main course}

The user interface for the main menu can be seen in Figure 12 below:
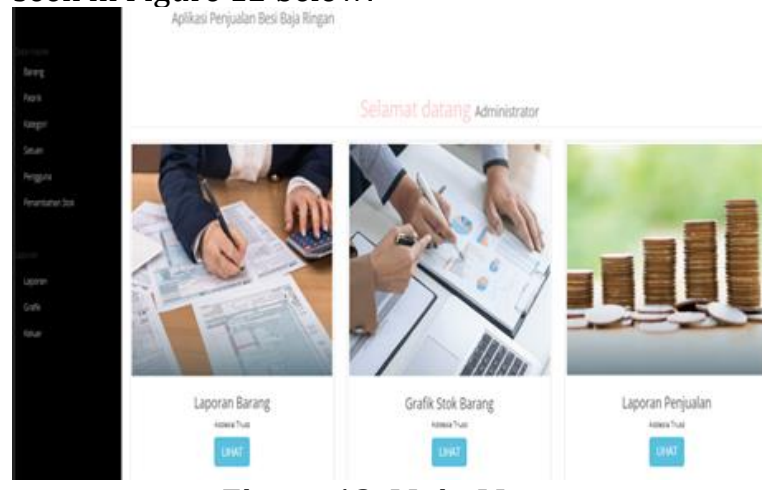

Figure 12. Main Menu

Figure 12, A menu related to the sales information system is provided on the main menu page. If you are logged in as an admin, you can access the master data menu, item menu, factory menu, category menu, user menu, stock additions, and reports. Meanwhile, you can access the transaction menu, sales return menu, and sales journal if you enter sales.

\section{c. Item Data Display}

The user interface for displaying item data can be seen in Figure 13 below: 


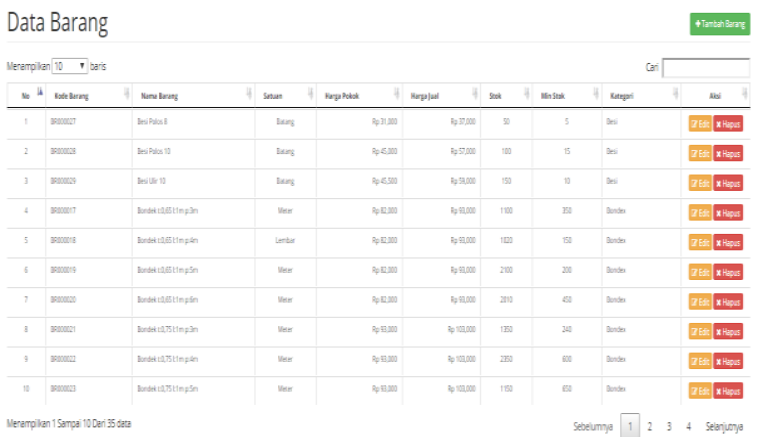

Figure 13. Item Data Display

\section{d. User Data Display}

The user interface for displaying user data can be seen in Figure 14 below:

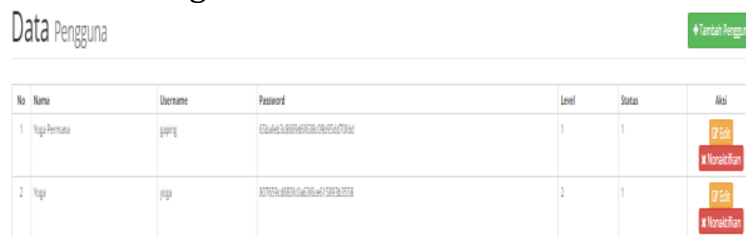

Figure 14. User Data Display

\section{e. Sales Transaction Display}

The user interface for sales transactions can be seen in Figure 15 below:

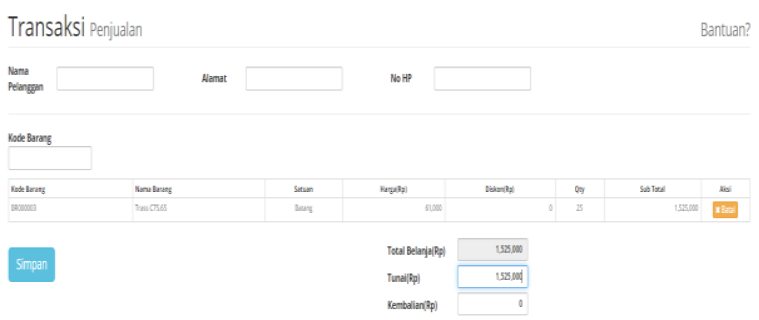

Figure 15. Sales Transaction Display

\section{f. Sales Journal Display}

The user interface for the sales journal can be seen in Figure 16 below:

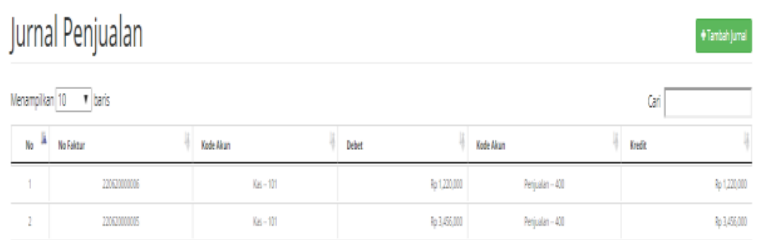

Figure 16. Display of Sales Journal

\section{g. Report View}

The user interface for the report can be seen in the following figure 17 :

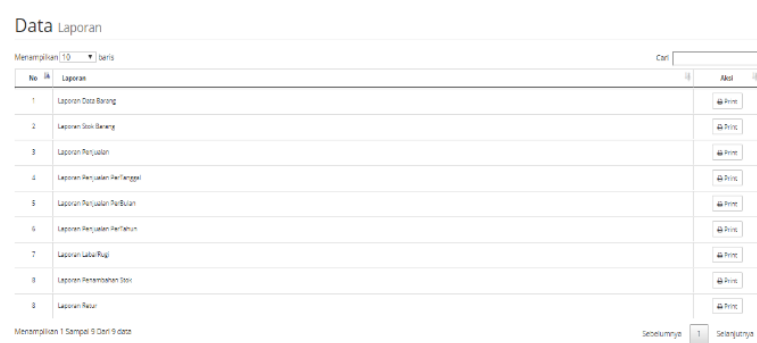

Figure 17. Report Display

\section{PROGRAMMING CODE}

The program code used to manufacture this light steel sales information system uses the PHP programming language.

\section{E. TESTING}

Tests carried out in making this sales information system use black-box testing, as can be seen in the following table:

\begin{tabular}{|c|c|c|c|}
\hline Step & Input & Excpeted Outcome & $\begin{array}{l}\text { Test } \\
\text { result }\end{array}$ \\
\hline 1 & $\begin{array}{l}\text { create a } \\
\text { new } \\
\text { order for } \\
\text { any one } \\
\text { standard } \\
\text { order } \\
\text { item }\end{array}$ & $\begin{array}{l}\text { Order confirmation } \\
\text { message displayed }\end{array}$ & Succeed \\
\hline 2 & $\begin{array}{l}\text { Enter the } \\
\text { item code } \\
\text { with } \\
\text { keywords }\end{array}$ & $\begin{array}{l}\text { The item searched } \\
\text { data appears }\end{array}$ & Succeed \\
\hline 3 & $\begin{array}{l}\text { Re-enter } \\
\text { the item } \\
\text { code with } \\
\text { the } \\
\text { keyword } \\
\text { for the } \\
\text { second } \\
\text { item }\end{array}$ & $\begin{array}{l}\text { Two items appear in } \\
\text { the transaction }\end{array}$ & Succeed \\
\hline 4 & $\begin{array}{l}\text { Cancel the } \\
\text { order }\end{array}$ & $\begin{array}{l}\text { Sales order } \\
\text { cancellation notice } \\
\text { and delete items }\end{array}$ & Succeed \\
\hline 5 & $\begin{array}{l}\text { Enter the } \\
\text { required } \\
\text { number }\end{array}$ & $\begin{array}{l}\text { Money-back will } \\
\text { appear }\end{array}$ & Succeed \\
\hline 6 & $\begin{array}{l}\text { Print sales } \\
\text { invoice }\end{array}$ & $\begin{array}{l}\text { Invoice printed } \\
\text { according to sales } \\
\text { order } \\
\text { items appear in the } \\
\text { transaction }\end{array}$ & Succeed \\
\hline
\end{tabular}

\section{F. Support}

Development of the system that will be made to deal with developments and changes in the system, 
related to the hardware and software that will be used, in this case the author uses hardware and software.

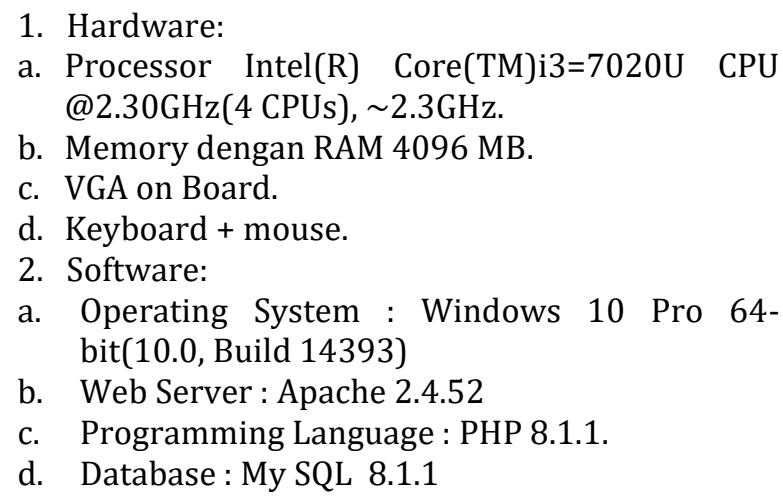

\section{CONCLUSIONS AND SUGGESTIONS}

\section{Conclusion}

The design of the Accounting Information System for Sales of Light Steel in cash aims to facilitate business entities or companies in handling the sales process and financial defects or financial reports. By using this information system, it is hoped that the sales transaction process that occurs in the company is more well organized, so that the effectiveness and efficiency of the company or business entity's work increases, reduce errors in processing sales data, and the security of data on sales of goods is guaranteed and not easily lost.

\section{Suggestion}

The author's suggestion for this research is that periodic maintenance and updates are needed according to the needs of the company or business entity with this information system. In addition, it is necessary to hold training or training for users who will use this information system so as not to cause errors in carrying out sales transactions.

\section{REFERENCES}

Aediyansyah, A. (2018). Perancangan Sistem Informasi Penjualan Daur Ulang Botol Bekas (Pet) Berbasis Web. Jurnal Riset Informatika, 1(1), 11-16. https://doi.org/10.34288/jri.v1i1.5

Darmawan, A., \& Firmansyah, S. (2018). Pengaruh Penjualan Kredit Terhadap Kinerja Perusahaan Di Indonesia. Akuntabilitas, 11(1), 135-146. https://doi.org/10.15408/akt.v11i1.8823

Frieyadie. (2019). Logical Record Structure (LRS). Retrieved. http://frieyadie.web.id/logicalrecord-structure-lrs/

Hartono, W. J. (2018). Perancangan Sistem
Akuntansi Penjualan Tunai Pada Toko Satria Ponsel Pekanbaru. 9, 2000-2023.

Iriadi, N., \& Rosdiana, N. (2017). Perancangan Sistem Informasi Penjualan Minuman Kemasan Berbasis Web Pada Toko Bambu Sejahtera Bekasi. Jurnal Khatulistiwa Informatika, $V(1), 42$.

Maknunah, L. U., \& Lestari, P. (2018). Analisis Komparatif Penjualan Tunai Dan Kredit Terhadap Keputusan Pembelian Baju Muslim Anak Merk Dannis. Translitera : Jurnal Kajian Komunikasi Dan Studi Media, 7(2), 44-59. https://doi.org/10.35457/translitera.v7i02.5 92

Muthia, N., Amalia, H., Puspita, A., \& Lestari, A. F. (2019). Rancang Bangun Sistem Informasi Akuntansi Penjualan Dengan Model Waterfall Berbasis Java Desktop. JITK (Jurnal Ilmu Pengetahuan Dan Teknologi Komputer), 5(1), 15-22. https://doi.org/10.33480/jitk.v5i1.582

Oktaviani, A., Nogie, M., \& Novianti, D. (2020). WebBased Equipment Inventory Information System in the Service Division of Pt Arista Sukses Mandiri Jakarta. Jurnal Riset Informatika, 3(1), 31-38. https://doi.org/10.34288/jri.v3i1.174

Prasetyo, A., \& Susanti, R. (2015). Sistem Informasi Penjualan Berbasis Web Pada PT. Cahaya Sejahtera Sentosa Blitar. Jurnal Ilmiah Teknologi Informasi Asia, 10(2), 1-16.

Puspita, A., Fahmi, M., \& Yuningsih, Y. (2019). Perancangan Dan Pembuatan Aplikasi ELearning Menggunakan Model Waterfall Pada Sekolah Menengah Atas. Jurnal Riset Informatika, 1(4), 173-180. https://doi.org/10.34288/jri.v1i4.94

Riswaya, A. R. (2013). Sistem Penjualan Tunai Dan Kredit Property. 7(2), 106-116.

Sitorus, Maria Christina \& Kuriawan, A. (2021). Profitabilitas Perusahaan Pada Pd Gloria Bandung. Jurnal Financia, 2(1).

Sudaryono, \& Rahwanto, E. (2020). Perancangan Sistem Informasi Penjualan Berbasis Web Pada Pt. Inter Aneka Plasindo. Jurnal Pendidikan Dan Dakwah, 2(3), 335-358. https://ejournal.stitpn.ac.id/index.php/pand awa

Susanti, S. (2019). Sistem Informasi Evaluasi Karyawan Berbasis Web Pada Pt Praweda Ciptakarsa Informatika Jakarta. Jurnal Riset Informatika, 1(3), 147-152. https://doi.org/10.34288/jri.v1i3.104

Yuningsih, Y. (2019). Metode Delone dan Mclean Dalam Kepuasan Konsumen Terhadap Aplikasi Shopee. 6(1), 55-64. 